\title{
The Universal Language Phenomena in the Translation of English Modality into Indonesian
}

\author{
Deden Novan Setiawan Nugraha, Universitas Padjadjaran
}

\begin{abstract}
Modality is one of the language universal phenomena. This means that modalities can appear in all languages with their respective forms of disclosure. By using descriptive method, this research describes the futurity modalities in English and Indonesian based on its structure and meaning. The data was taken in various written language of the novel in English and in Indonesian. The results showed that the futurity modalities in Indonesian are expressed by mau, hendak, akan with meaning keteramalan and keinginan, whereas in English the futurity modality is expressed by will and shall with meaning prediction and volition (desire).
\end{abstract}

Keywords: modalities; mode; universal language

\section{Introduction}

The language has the main function as a communication tool. Every language has a very important role because it is used as the identity of a country and the result of human thinking that serves the delivery of ideas, messages and purpose of the speaker. One of the languages in the spotlight of Asean Economic Society (Masyarakat Ekonomi Asean - MEA) is Indonesian. This is because Indonesia is a country with the largest population in the Asean region and has the highest economic growth in the world after China and India based on World Bank data in 2016. Thus, Indonesia has a very wide impact not only in economics, education and culture but also in language. Responding to such situations, it is not wrong if many foreigners study the Indonesian language using English introduction.

Chomsky (in Alwasilah, 1984: 6) argues that the reason for learning the language is a reflection of the mind and the intent of the speaker. For the process of conveying the intent in Indonesian and English, the speakers can use modalities.

The term of modalities is derived from the English language that is modality, which distinguished its meaning with the mood or mode. Hasanudin et al (2009: 772) mentions that the modalities are: (1) Classification of propositions refers to things presenting or denying the possibility or necessity; (2) The manner refers to how the speaker expresses an attitude for the situation in an interpersonal communication; (3) The significance of the possibility, necessity, of reality expressed in the sentence. Meanwhile, Alwi (1992: 259-261) divides the type of modalities into four. There are namely intentional modalities, epistemic modalities, deontic modalities, and dynamic modalities. First, intentional modality is modalities that express the meaning of desire, hope, and invitation. Second, epistemic modalities are modalities that express the possibility, conformity, certainty and necessity (1992: 90). Third, deontic modalities are modalities that express permission or command (1992: 163). Fourth, dynamic modality represents a modality that states ability (1992: 233).

(1) Tuan George, maukah tuan pergi ke rawa denganku, akan kutunjukkan serumpun teratai. (PHF: 177).

The Indonesian sentence above is containing the futurity of modalities expressed by the mode of will. Huddleston (2002: 173) states that "Modality is concerned with the speaker's attitude towards the factuality or actualization of the situation expressed by the rest of the clause".

(2) He wrote it himself.

The sentence he wrote it himself above categorizes a declarative clause and contains no modalities because it does not indicate the level of speaker commitment or conviction.

(3) He must have written it himself.

The sentence he must have written it himself is a declarative clause that has modalities because it indicates the level of commitment or confidence of the speaker. The statement can 
demonstrate a strong commitment which is clarified by the existence of auxiliary verb capital which is expressed by the mode of must. The must is to convey the subjective meaning of necessity because of the involvement of the speaker's authority in the statement. Given this modality, speakers can signal how strong or weak the commitment to a factual statement.

Lyons (in Alwi, 1992: 2) argues that mode usage is seen in the form of special verbs, as in languages belonging to the Indo-European family. In general mode is expressed by the verb form, so it can be included in the syntactic category, not the semantic category, while the modalities are categorized into the semantic category.

There are different ways of expressing the mode in Indonesian and English. Disclosure of the mode in Indonesian uses lexical elements, meaning that the form of the language used is classified as a word, phrase or clause. For example, adverbs that are seharusnya and barangkali, and clauses that are saya kira and saya ingin.

Disclosure mode in English can use grammatical elements and lexical elements. Grammatical elements are seen in the use of capital auxiliary verbs such as can, must, shall, must, will and will, while lexical elements, Huddleston (2002: 173) called it lexical capital (lexical modals), is to show a meaningful expression equal to the auxiliaries of verb capital, but not in the syntactic category of auxiliary verbs. These include adjectives, adverbs, verbs, and nouns. Examples of such adjectives: possible, necessary, likely, probable, bound (must), supposed (supposed). Examples of Adverbs such as: may, possibly, necessarily, probably, certainly (surely). Examples of verbs such as insist, permit, require, while nouns such as possibility, necessity, and permission.

Modality can appear in all languages with their respective forms of disclosure. In addition to different perspectives, it can also be seen the classification of modalities expressed by both Indonesian and foreign language experts. Alwi (1992) and Sudaryanto (1983) mentioned that there are four forms of modalities: intentional modalities, epistemic modalities, deontic modalities, and dynamic modalities. Quirk et al (1985: in Alwi, 1992: 13) mentions two forms of modalities: intrinsic modalities and extrinsic modalities. Ransom (1977: in Alwi, 1992: 13) mentions two forms of modalities namely truth modality and control modality. Halliday (1985: in Alwi, 1992: 13) mentions two modes of modulation and modalization, while Lyons (1977) parallels Alwi's four modal modes used in natural languages 'natural languages'. Lyons gives a view of forms of modality based on rational, social, and natural laws.

In terms of modalities, linguists also use different terms. Alisjahbana (1983: 112, 1957: 79) uses the term 'adverbs of the word' (description of modalities). Poerwadarminta (1967: 74) and Slametmuljana (1957: 366) use the same term 'extra word'. Poerwadarminta in its description mentions that modalities can be expressed by using intonation, supplementary words, connecting words, verbs, and phrases.

Furthermore, Samsuri (1985: 249) uses the term 'auxiliary verb'. Kridalaksana (1986) suggests that modalities can be in the form of 'adverbs of modalities' such as akan, belum, boleh, dapat, harus, jangan, kagak, nggak, tidak, mungkin, and barangkali. Alwi (1992) uses the term 'modal auxiliary verbs'.

Based on the above description, with regard to modalities, both Indonesian and English language specialists use different terms, and perform different classifications. These causes the foreign learners of Indonesian have difficulty to understand the modalities, one of them is about the futurity modalities. The futurity modality means the speaker's attitude to the statement which describes the use of speech as a point of view in considering the circumstances at the actualization of the event.

In English, the futurity modality exists in the grammatical element that is in the use of auxiliary verbs. This has a lot of complexity because each auxiliary verb has a diverse understanding that is determined by the context of the sentence. Auxiliary verbs have changed because in every language speaker uses auxiliary verbs with different meanings depend on his likes (Kreidler, 1998: 240).

Considering the above description, there is a general difference between Indonesian and English. Indonesian and English are languages that are not cognate, each having differences, not 
only in culture and language but also in the disclosure of the mode and meaning of the futurity modalities.

In relation to the background above, this research aims to describe what modes express the modalities of futurity in Indonesian and English and describe the meaning of any futurity modality contained in the English language. The data are the various written languages with the consideration that the various written show a more consistent characteristic of oral variety, both in the use of sentence structures and word choices (Alwi 1992: 25). The source of the data is the novel entitled The adventures of huckleberry finn by mark twain and its translation in Indonesian entitled Hackleberry finn's adventure by Djokolelono.

\section{Method}

The method used in this research is descriptive research method. The use of descriptive method is considered focus attention on the characteristics and nature of the language data naturally so as to produce valid data to be analyzed (Djajasudarma, 1993).

The technique in this research begins with data collection by using technique record, record data on data card as population from source data. The data is classified the similarities and differences of syntactic and semantic behavior. Then proceed with the conclusion of research results as an answer to the problem under study. The method of study used is the method of distributional study, is a study that elements of determining is in the language itself (Djajasudarma, 1993). The study technique used is the technique of deletion, technique of substitution, and element transfer technique (permutation).

\section{Theoretical framework}

\subsection{Syntactic}

Syntax is derived from Greek which consists of two words "sun" which means "with" and "tattein" which means "placing". Etymologically syntactic means putting together words into groups of words or sentences (Chaer, 2003: 70), while Miller (2002: 56) argues that syntax has to do with how words are put together to build clauses, or bigger phrases, and with how clause are put together to build sentences. That is, syntax relates to how words are placed together to form larger clauses or phrases and how clauses are placed together to form sentences.

From the above definition, it can be concluded that syntax is a branch of language science studies how a group of words arranged into a sentence. Syntax is divided into several units. These units are words, phrases, clauses, and sentences. The word is the smallest unit, while the sentence is the largest unit. The four syntactic units are hierarchical, which means they are composed of the highest to the lowest order.

\subsection{Syntactic functions}

Syntactic functions in Indonesian and English have the same elements, which include subject functions, predicate functions, object functions, complement functions, and adverbial functions.

\subsection{Syntactic category}

The syntactic category is a class word term or in traditional English grammar called parts of speech, whereas in modern grammar it is called word classes which basically have the same meaning. Richards and Schmidt (2013) state that part of speech is a traditional term to describe the different types of words which are used to form sentences, such as noun, pronoun, verb, adjective, adverb, preposition, conjunction, and interjection.

In Indonesian, the syntactic category includes two parts, the first part being the verb, adjective, adverbial, and noun, while the second part is the preposition, and the conjunction.

\subsection{Verbs in Indonesian}

According to Alwi, et al (1993: 93), verb contains the inherent meaning of actions (actions), processes or circumstances that are not properties or qualities that serve as the predicate or predicate core, while Kridalaksana (2005: 49) suggests that the verb is a grammatical unit, it can be known that the categorization of a verb is only from its behavior in the phrase, it cannot 
be accompanied by that unit with particles $d i$, ke, dari or with particles such as sangat, lebih, atau agak. For examples: tidur, makan, minum.

\subsection{Verbs in English}

Deterding, et al. (2001: 36) states that verbs are the key elements in sentences, whereas according to Hornby (1975:132) a verb is word or phrase indicating an action, an event, or a state.

\subsection{Semantics}

Hurford and Heasley (1983: 1) state that semantics is the study of meaning in language. In line with Hurford and Heasley, O'Grady (1997: 268) states that semantics is the study of meaning in human language. Saeed (2003: 3) states that semantics is the study of meaning communicated through language. It can be concluded that semantics are generally defined as the study of the meaning communicated through language.

The object of semantic study is the meaning. Quirk, et al. (1985: 5) states that meaning is that which you are intended to understand by something spoken or written or expressed in other ways. Lyons (1981: 136) states that meaning is ideas or concept which can be transferred from the mind of hearer by embodying them as it were in the forms of one language or another.

\subsection{Modalities}

Kridalaksana (1982a: 107) argues that modalities in linguistic terms are a classification of propositions according to terms of presenting, denying, or necessitating; can also mean the way the speaker in expressing his attitude towards an event with the meaning of the possibility, certainty, necessity, prohibition, and others. While Chaer (1994: 262) states that what is meant by modalities is a statement in the phrase that states the attitude of the speaker to the matter being discussed, that is about the actions, circumstances, events, or attitudes towards the interlocutor. This attitude can be a statement of possibility, desire, necessity or permission.

3.8 The differences between modes and modalities

Huddleston (2002: 172) states that the distinction between mood and modality is like that between tense and time, or aspect and aspectuality: mood is a category of grammar, modality a category meaning. Mood is the grammaticalization of modality within the verbal system". In line with Huddleston, Young (1980: 45) defines a mood as follows:

Mood is the name given to those grammatical systems that expresses the speakers' relation to a proposition but this kind of meaning does not concern only the speaker and the proposition. Speakers take up attitudes towards what they are saying for the sake of the communicating with other people; addresses are necessarily involved and the speaker may impute to the addressee some relationship to the proposition.

From the above description, it can conclude the mode differs with the modalities. Mode is a grammatical category or forms expressing modalities whereas modalities are categories of meaning.

\subsection{Types of meaning of modality}

Semantically, the type of meaning of modalities in English according to Huddleston (2002: 177-179) uses the same term as Perkins (1983) and Palmer (1988: 96-97) in classifying the modalities of meaning in three categories: Epistemic modalities, deontic modalities, and dynamic modalities.

In the Indonesian, according to Alwi (1992-259-261) there are four types of modalities, namely intentional modalities, epistemic modalities, deontic modalities, and dynamic modalities. As for the explanation, first Intentional Modality is a modality that expresses the meaning of desire, hope, and invitation. Second, epistemic modalities are modalities that express the possibility, conformity, certainty and necessity (1992: 90). Third, deontic modalities are modalities that express permission or command (1992: 163), while the fourth is dynamic modality, representing a modality that states ability (1992: 233).

\subsubsection{Epistemic modality}

Huddleston (2002:178) states that Epistemic is derived from Greek for knowledge: this kind of modality involves qualifications concerning the speaker's knowledge.

In line with Huddlestton, Perkins (in Alwi, 1992: 89) states that the term knowledge is defined as lack of knowledge, whereas Coates (in Alwi 1983: 89) defines it as lack of confidence. 
Perkins concludes that what is in question in the epistemic modality is the attitude of the speaker based on the rationale or reasoning of the speaker on his belief or lack of faith in the truth of the proposition. Epistemic modalities include probability, predicament, necessity, or certainty (in Alwi, 1992: 91). Coates (1983:18) provides the following example:

(103) Paul must be in Liverpool by now.

The example he puts forward, that must be an epistemic modality meaning possibility. The speaker's assumptions in the above example, according to Coates, can be paraphrased: I assume that by what time of the day is he leaving, what time is he now, and what is the state of public transportation, Paul is now in Liverpool. He argues that the speaker's assumption explains the fact that the epistemic meaning must involve the speaker in logical conclusion even though the facts underlying that conclusion are often not stated. This opinion is in line with Perkins's (1983) view of the rationale or reasoning power of the speaker which is the benchmark of epistemic modalities. The engagement of the speaker in providing an assessment of the truth of the proposition causes a subjective, subjective epistemic modality. (Leech, 1971: in Palmer, 1974,1979).

\subsubsection{Deontic Modality}

Huddleston (2002:178) states that deontic is derived from Greek for binding so that here it is a matter of improving obligation or prohibition, granting permission, and the like. The person, authority, convention, or whatever from the obligation, etc. is understood to emanate we refer to as the deontic source. See the following example:

(104) You must pull your socks up.

The example above shows speakers as a deontic source that gives commands to the subject to release socks. In line with Huddleston, according to Alwi (1992: 163) deontic modalities are the attitude of the speaker to events based on social rules. Social rules can be in the form of personal authority or official authority. Personal authority is caused by differences in age, position, or social status between a person and another person, whereas the official authority comes from a mutually agreed provision or regulation to govern the livelihood of the community. Both types of authority are a deontic source that will encourage a person to become an actualization actor. Deontic modality is subjective; this means speaking that gives commands, permission, or even a ban on someone to do something.

\subsubsection{Dynamic modality}

Alwi (1992: 163) states that dynamic modality is a speaker's attitude toward the actualization of events based on more empirical circumstances so that, according to Perkins (1983: 10-11), which is used as a benchmark by the speaker is the law of nature laws of nature. Dynamic modality is objective because the continuity of the event is independent of the speaker, but on the subject acting as an agent in this case is seen in the meaning of ability. In the Indonesian, dynamic modalities include capability modalities expressed through dapat, sanggup, bisa, and mampu.

\subsection{The futurity modality in Indonesian}

Alwi (1992: 43) argues that the modalities of keakanan in Indonesian appear on mau, hendak, and akan. The use of the three modes illustrates the use of speech as a point of view in considering circumstances at the actualization of events. See the following examples:

a. Saya mau mengambil dua karcis pertaruhan lagi untuk dia.

b. Hampir saja mereka hendak memukul karena merasa dipermainkan.

c. Dari kunjungannya selama dua minggu ke Republik rakyat Cina, Perdana Menteri Singapura Lee Kuan Yew mendapat kesan, RRC akan menghentikan hubungannya yang aktif dengan partai komunis di Negara-negara Asean.

\subsection{The Futurity Modality in English}

Quirk (1985: 228) divides the mode of will which means prediction into three namely: The common future predicative, the present predictive sense, and the habitual predicative. See the following explanations: 


\subsubsection{The common future predicative}

The intention is to predict what will happen next in general over previous events that have been done and usually followed by future time information (future) such as next, tomorrow, later, and so forth. Meaningful sentences the common future predicative is usually still an estimate or prediction that is not certain to happen in accordance with the estimated time or prediction that has not been confirmed according to the estimated time is still vague so that most sentences using the future or simple future tense. Example: You will take the train next two hours.

\subsubsection{The present predictive sense}

The point is a prediction that states the necessity or possibility of something that is happening right now. Actually, this meaningful sentence is rarely found. Example: That'll be the postman (on hearing the doorbell ring).

\subsubsection{The habitual predicative}

The habitual predicative is a prediction that is common in everyday life and is certainly true without being denied the truth. Example: Oil will float on water.

\section{Results and Discussion}

The results of the analysis show that the mode used to express the modalities futurity in the Indonesian language are mau, hendak, akan with equivalent meaning. While in English is expressed with the mode will and shall mean prediction and volition.

\begin{tabular}{|l|l|}
\hline \multicolumn{1}{|c|}{ English } & \multicolumn{1}{c|}{ Indonesian } \\
$\begin{array}{l}\text { "Give a nigger an inch and he will take en } \\
\text { ell." (THF:86): }\end{array}$ & $\begin{array}{l}\text { "Berilah seorang Negro Sejengkal' dan ia } \\
\text { akan mengambil sehasta." (PHF:144) }\end{array}$ \\
\hline
\end{tabular}

The mode of will used in the sentence above shows prediction and belongs to the common future predicative. This is because the event has not occurred yet. The use of the mode will be the mode translation in the context of the preceding sentence precisely because it describes the use of the speech as a point of view in considering the circumstances of the actualization of the event.

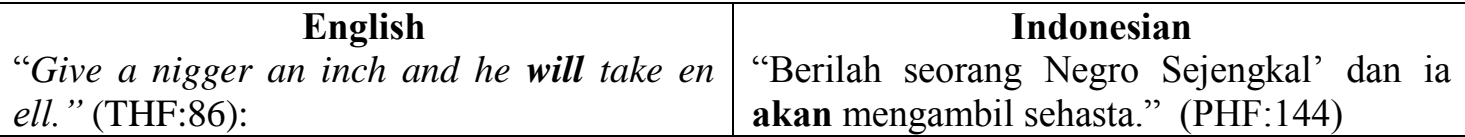

\section{Acknowledgments}

I would like to thank all parties who contributed to this study completed under supervision and collaboration insights. The research itself was supported by PDD grant of Ministry of Research, Technology and Higher Education. Thank you very much for the valuable support.

\section{References}

Alwi, H. 1992. Modalitas dalam Bahasa Indonesia. Yogyakarta: Kanisius. Chaedar, A. 1984. Linguistik: Suatu pengantar. Bandung: Angkasa.

Chaer, A. 1994. Linguistik Umum. Jakarta: Rineka Cipta.

Deterding, D.H. \& Poedjosoedarmo, G. R. 2001. Grammar of English. Singapore: Prentice Hall. Djajasudarma, T. F. 1993. Metode Linguistik: Ancangan Metode Penelitian dan Kajian. Bandung: PT. Eresco.

Djokolelono. 1975. Petualangan Huckleberry Finn. Jakarta: Pustaka Jaya.

Halliday, M. A. K. 1985. An Introduction to Functional Grammar. London: Edward Arnold. Hornby, A. S. 1975. Guide to Patterns and Usage in English. London: Oxford University Press. Huddleston, R. D., \& Pullum, G. K. 2002. The Cambridge Grammar of the English Language. Cambridge, UK: Cambridge University Press. 
Hurford, J. R \& Heasley, B. 1983. Semantics: a course book. Cambridge. Cambridge University Press.

Kreidler, C. W.1998. Introducing English Semantics, London: Routledge.

Kridalaksana, H. 1982. Kamus Linguistik. Jakarta: PT. Gramedia Pustaka Utama.

Kridalaksana, H. 1986. Sintaksis. Jakarta: Proyek Pengembangan Bahasa dan Sastra Indonesia dan Daerah. Departemen Pendidikan dan Kebudayaan.

Kridalaksana, H. 1988. Beberapa Prinsip Perpaduan Leksem dalam Bahasa Indonesia. Seri ILDEP . Yogyakarta: Penerbit Kanisius.

Leech, G. N. 1971. Meaning and the English Verb. London: Longman.

Lyons, J. 1977. Semantics. Cambridge University Press.

Lyons, J. 1981. Language, Meaning and Context. Cambridge University Press.

Miller, J. 2002. An Introduction to English Syntax. Cambridge University Press.UK.

O'Grady, W., Dobrovolsky, M. \& Katamba, F. 1997. Contemporary linguistics. London: Longman.

Palmer, F. R. 1988. Mood and Modality. Cambridge: Cambridge University Press.

Palmer, F.R.1974. The English Verb. London: Longman.

Palmer, F.R.1979. Modality and the English Modals. London: Longman.

Perkins, M. R. 1983. Modal Expressions in English. Norwood: Ablex Publishing Corporation.

Poerwadarminta, W. J. S. 1967. Bahasa Indonesia untuk karang-mengarang. Yogyakarta: UP Indonesia.

Quirk, R., Greenbaum, S., Leech, G., \& Svartvik, J. 1985. A Comprehensive Grammar of the English Language. London: Longman.

Ransom, E. N. 1977. On the Representation of Modality. Linguistics and Philosophy. Dordrecht: Reidel.

Richards, J. C., \& Schmidt, R. W. (2013). Longman dictionary of language teaching and applied linguistics. London: Routledge.

Samsuri. 1985. Tata Kalimat Bahasa Indonesia. Jakarta: Sastra Hudaya.

Slametmuljana. 1957. Kaidah Bahasa Indonesia II. Jakarta: Djambatan.

Sudaryanto. 1983. Predikat-Objek dalam Bahasa Indonesia: Keselarasan Pola-Urutan. Seri ILDEP. Jakarta: Djambatan.

Twain, M. 1965. The Adventures of Huckleberry Finn. New York; Bantam Books, Inc.

Young, J. D. 1980. The Structure of English Clauses. Sydney: Hutchinson. 